\title{
Comparison of Indonesian and Malaysian Legal Systems in Rules, Traditions, and Community Behavior
}

\section{Siti Zuliyah}

Faklutas Hukum, Universitas Ahmad Dahlan

siti.zuliyah@law.uad.ac.id

DOI: dx.doi.org/10.23917/jtl.v3i1.15169

\begin{abstract}
Submission
Track:

Received:

14 July 2021

Final Revision:

29 September 2021

Available online:

30 September 2021

Corresponding

Author:

Siti Zuliyah

siti.zuliyah@law.uad.ac.id

\section{ABSTRACT}

This article aims to compare the legal system in Indonesia with the legal system in Malaysia by looking at the similarities and differences between the two countries legal systems. In this paper, we use a normative juridical approach, which is to examine the laws and regulations as well as the attitudes and behavior patterns of citizens towards the law and legal system in force in a country based on secondary legal sources consisting of legislation and other related documents. The results of the discussion conclude that in general both Indonesia and Malaysia have similarities in terms of: (1) The structure of the highest judicial institution along with the judicial institutions below it as well as the implementing institutions of statutory regulations. (2) Regulations, rules and real behavior patterns in various fields of life of the citizens concerned. (3) Attitudes towards the law and the legal system of citizens are in the form of beliefs, values, awareness, ideas and hopes that make the legal process work. Meanwhile, specifically between Indonesia and Malaysia have differences due to: (1) Legal structures influenced by local or domestic and global legal traditions. (2) Legislative regulations whose formulation is influenced by local or domestic and global legal traditions. (3) The legal process runs according to the situation, conditions and problems faced by the country concerned.
\end{abstract}

Keywords: Comparison of the legal system, the legal system in Indonesia, the legal system in Malaysia. 


\section{INTRODUCTION}

With regard to legal traditions in various countries, including those that are members of the Association of Southeast Asian Nations (ASEAN), we know the division of John Henry Merryman in his book The Civil Law Tradition (1969). There are three main legal traditions, namely the continental legal tradition (civil law), the customary law tradition (common law), and the socialist legal tradition (socialist law). (Nusantara, 1986, p. 154-155)

Bagir Manan explained that the role of legislation in a country depends on the legal tradition adopted by the country concerned. There are two main groups of legal traditions (principal) in this world, namely the continental legal tradition (civil law tradition) and the anglo-saksis legal tradition (common law tradition). There are also those who divide the legal tradition into three groups, namely in addition to the two legal traditions, there is a third legal tradition, namely socialist law tradition. The grouping into two or three legal traditions is more historical and academic in nature. In reality, there are legal systems (a country) which at the same time contain the characteristics of the continental legal tradition and the anglo-saksis legal tradition, a combination of continental law and the anglo-saksis legal tradition, a combination of the continental legal tradition and the socialist legal tradition, or a combination between the anglo-saksis legal tradition and the socialist tradition. There are also legal systems that cannot be classified into one of the three groups above, for example countries that identify themselves with the legal tradition according to Islamic teachings (the moslem legal tradition).

The difference between the continental and Anglo-saksi legal traditions is based, among other things, on the role of statutory law and jurisprudence. Countries that are members of continental law place statutory law as the main framework of their legal system, while countries that adhere to the anglo-saksis legal tradition make or place jurisprudence as the main framework as their legal system. Slightly different from the socialist legal tradition. The socialist legal tradition is not primarily based on the role of statutory law or jurisprudence, but on the basis of economic and social policy. According to this view, law is an instrument (tool) of policy in the economic and social fields, while the continental and anglo-saksis legal traditions are seen as a reflection of a 
capitalistic, bourgeois, imperialist, and exploitative society and government. (Riyanto, 2017)

The continental legal tradition places statutory law as the main framework of its legal system, this does not mean that the continental legal tradition ignores jurisprudence. In such countries, jurisprudence still has a legal source. Likewise, in countries that carry out the anglo-saksis legal tradition, this does not mean ignoring the statutory law. Legislation in anglo-saksis countries is growing rapidly and is increasingly occupying an important role. Driven by the development of science and technology as well as the common need in international relations (international association), various legal traditions and legal systems try to bring each other closer and make adjustments (harmonization) with each other. (Riyanto, 2017)

With various differences between them, but the similarity of conception in the socialist legal tradition is one of the characteristics of these socialist countries. Likewise, the legal tradition according to Islamic teachings. At this time seen various activities that show the revival of Islam. This revival was not solely due to the awareness of moslem community itself, but was also stimulated by the increase in scientific activities that made Islam the object of investigation. This revival will certainly have an effect on efforts to make Islamic law a positive law. Or at least make it a topic that cannot be ignored in legal politics, especially legislative politics. (Manan, 1995, p. 18-20).

In this article, we will discuss further the comparison of the legal system in Indonesia with the legal system in Malaysia by looking at the similarities and differences in the legal systems of the two countries including the structure of the judiciary, regulations, rules and real behavior patterns in various fields of life of the citizens concerned, attitudes towards the law and the legal system of the citizens. As well as legal structures, statutory regulations and legal processes that are influenced by local or domestic and global legal traditions.

\section{RESEARCH METHOD}

In this paper, we use a normative juridical approach, which is to examine the laws and regulations as well as the attitudes and behavior patterns of citizens towards 
the laws and legal systems in force in a country based on secondary legal sources consisting of statutory regulations and other related documents.

\section{The Notion of Legal System}

According to Lawrence M. Friedman (1998), the legal system is everywhere with us and around us. Not a day goes by without dealing with the law in a broad sense, the law influences or changes people's behavior. The law is something very big, though sometimes invisible. Laws have a purpose - whether successful or not - to make life easier, safer, happier, or better. When norms (rules) prohibit something (or demand something from someone), usually the prohibition is condemned for the benefit of others. The law provides easy ways to achieve the expected goals. (Rahardjo, 1986, p. 88)

The word "law" often refers only to rules and regulations; but a line can be drawn between the rules and regulations themselves and the structures, institutions, and processes that bring them to life. This extended domain is called the "legal system”. The legal system contains more than just rules, regulations, orders and prohibitions. In the legal system there are rules about rules. There are rules of procedure and rules that distinguish rules from non-rules. H.L.A Hart calls the rules about these rules the "secondary rules", he calls the rules about real behavior the "primary rules". According to H.L.A Hart, law is a compilation of primary and secondary rules. (Friedman, 1998, p. 15-18)

\section{Elements in Legal System}

Lawrence M. Friedman suggests that we now have a basic idea of what we mean when we talk about the legal system. There is a way to analyze the shape of this complex and important social world. The legal system has a "structure”. The system is constantly changing and not every part changes as fast as the other parts. There are patterns that last a long time, namely aspects of the legal system that have existed before and will continue to exist for a long time. This is the structure of the legal system framework or framework, the part that is durable, namely the part that gives shape and form to the legal system as well as the whole. In one sense, the structure is a representative picture of a legal system. 
Another aspect of the legal system is its "substance", namely the real regulations, rules, and behavior patterns of the people in the legal system. This substance is law in the sense of fact. On the basis of this "substance" the police act against violations of the law. These are the working patterns of the law of life. Substance also means the product that people in the legal system make, the decisions they make, the new rules they make.

In this description the emphasis is placed on living law, not just on the rules in the law books. This brings us to the third component of the legal system, namely "legal culture”. Legal culture is people's attitudes towards the law and the legal system, their beliefs, values, ideas, and expectations. Legal culture is part of the general culture related to the legal system. Legal culture is the climate of social thought and social forces that determine how law is used, avoided, or abused. Without this legal culture, the legal system is helpless like a dead fish floating in a basin. The legal culture keeps the legal process running.

Another way to explain these three elements of law is to imagine the "structure" of law as a machine. Substance is what the machine makes or does. "Legal culture" is anything or anyone who decides to turn on or off a machine and determines how it is used.

Every nation, every country, every society has a legal culture. There are always attitudes and opinions about the law. Of course, this does not mean that everyone in a society has the same thoughts or ideas. There are many subcultures. One of the most important subculture is the "insider" legal culture, they are judges and lawyers working within the legal system itself.

In general we know very little about the impact of decisions, even the immediate effects. Courts do not have a duty to know what happened to the litigants after they left the courtroom, or what happened to the public at large. (lawrence M. Friedman, 1998, :15-34)

\section{Indonesian Legal System}

Indonesian legal system has undergone a number of major changes, although the country is still working hard to finalize changes to its colonial legislation and build a 
unified national legal system, based on Pancasila and the 1945 Constitution. (Amos J. Peaslee. 1985: 338)

Before the Proclamation of Independence in August 1945, there were two types of civil courts, namely the European Courts (Raad van Justitie) and the District Court for the indigenous people (Landraad). Apart from these courts, there are courts of Islamic law for marriage and divorce (as well as inheritance) and matters between moslems.

After the Proclamation of Independence, many new national laws that were inconsistent with Dutch legislation were passed, including the Agrarian Law no. 5/1960, Law on Foreign Investment (PMA) No. 1/1967, Domestic Investment Law no. 6/1986, Marriage Law No. 1/1974, Criminal Procedure Code no. 8/1981, and the Taxation Law no. 9/1994. Because of this, many Indonesian procedural and substantive laws have changed. Indonesian law today is not the same as Dutch law.

A new Law on Foreign Investment was enacted in 1976 and parts of the rules contained in the Civil and Commercial Laws of 1848 (which before independence only governed Europeans and foreign easterners) regarding contracts, companies, trade, insurance, and banking became applicable to citizens. A native Indonesian who is involved in business, banking, and insurance activities. The Indonesian government is seeking legal unification for all Indonesian citizens through modernization and legal codification. The government gives priority to "less sensitive" parts of the law (such as contract law, corporations and the economy in general). "More sensitive” areas of law such as family and inheritance law are given more time and opportunity to develop. (ASEAN Law Association, 19-22)

Citing the opinion of Lawrence M. Friedman, Bagir Manan explained that law is not only defined as a series of principles and rules. The law towards a new Indonesia must also include the implementation and enforcement of the law as well as the public's attitude towards the law. As a system, especially in the context of new Indonesia, the law will include legal content (legal principles and rules), legal structure (law makers and implementers). From the various indications above, people's aspirations to the law are not only carried out by building legal awareness. No less important is the attitude of the apparatus in carrying out functions in the field of government or law. In a 
repression, people can be encouraged to obey the law. In such a situation it will not be effective, the people will fight, either secretly (such as disobedience) or open resistance. The culture of obeying the law is not something that is created, but that grows or is grown, among others, because the people feel that they have benefits from obedience to the law. Including obeying the law is the ability of the people to fight in an orderly and orderly manner against unfair and arbitrary legal rules or actions. (Bagir Manan, 2000, : $4-11)$

Bagir Manan said that in terms of the source of the system, the existing laws are still of various types, namely legal substance originating from the law entered by the Dutch as colonizers (in literature commonly called Western law), legal substance originating from religion (such as Islamic law), the substance of Indonesian people's law (customary law), and various new legal substances that were born after independence in the form of statutory regulations, judges' decisions, new habits, and laws formed as a result of international relations (international agreements or agreements). Both because of developments and the need for legal substance, legislation is the main source and foundation of the national legal substance system now or in the future. Both developments and needs, the substance of statutory law is the main axis and foundation of the national legal system now or in the future. (Bagir Manan, 2000, : 13)

Related to the problem of the legal structure in Indonesia recently. Bagir Manan said that this problem was related to the elements of law-forming, law-implementing, and law-enforcement. The implementation of the law includes the provision of legal services from the central to the regional levels. Providing legal services from the central to the regional levels. The provision of legal services is part of the bureaucratic system. Except for the provisions that prohibit civil servants from becoming party members or becoming party activists, practically there has been no change in the bureaucratic order. Local Government Law (Law No. 22/1999 replaced by Law No. 32/2004) and the Central and Regional Fiscal Balance Law (Law No. 25/1999 replaced by Law No. 22/2004) has not shown a change in the bureaucracy in the regions, except for the desire as DPRD (Indonesian Legislative Assembly) to reject the accountability of Regents, Mayors, Governors towards new replacements. The change of the Department or the 
change to become a "state ministry", without a careful planning is a political arbitrary rather than an administrative reform towards an efficient and clean state administration. A reform of the bureaucracy (bureaucratic reform, administrative reform) must be a major concern in addition to political reform. An unhealthy bureaucracy is not only related to efficiency and effectiveness, but also becomes a place for corruption, collusion and nepotism (KKN).

During the reform, both politically and governmentally, there has not been an integral strategy or planning regarding efforts to reform the bureaucracy.

In the field of law enforcement, we are faced with problems with the judiciary, the prosecutor's office, the police, law enforcement agencies within the bureaucracy (immigration, correctional facilities, customs, and taxation), and the role of legal advisers. The judiciary has received extraordinary attention. There is hardly a day without news of complaints about the judiciary. This gray and disgraceful practice also applies to other law enforcers. Starting from the practice on the side of the road to the examination rooms or detention.

It must be admitted that the judiciary is the final determinant of law enforcement. The judiciary is the last institution where people find or do not find justice. Therefore, judicial reform must be placed at the forefront of improving the law enforcement system. So far, one of the public's concerns has been regarding the independence of the judiciary. The judiciary must be absolutely separated from the government (Law No. 35/1999). An independent judiciary is a must in every country based on law.

It should be understood that without a mechanism of checks and balances, judicial independence can create a judicial orbitrary. Judges become completely free of supervision. Nor is it acceptable to make the judiciary accountable to a particular political body. Even if there is, it is not an accountability relation, but as a mechanism for legal action. For this reason, in a political institution a judicial commission can be formed which is in charge of supervising and legally controlling the behavior of judges. An independent judicial commission can also be formed which is tasked with overseeing and legally controlling the judges. Renewal measures must also be carried out on other law enforcers. There needs to be an integral arrangement regarding the 
function of the investigation, so that there is no overlap that will harm or complicate the search for justice. (Bagir Manan, 2000, : 8-10)

Regarding the problem of public perception of law (legal culture) in Indonesia, Bagir Manan said:

People's attitudes that lack appreciate or lack of respect for the law can occur for several reasons. (Bagir Manan, 2000, : 10-11)

1. There is a gap between the formal understanding of law and the law that lives in society.

2. There are various shortcuts that can be used to achieve certain goals.

3. The structure of a feudalistic society that opens the possibility of "privilege" for certain groups to get various exceptions before the law.

4. The low level of public trust in law enforcement officers or the bureaucracy is due to various unacceptable behavior.

5. In the current "ultra-free" atmosphere, the public's low appreciation of the law also occurs because the officials are anxious and even afraid of various threats such as human rights violations and so on.

\section{Malaysian Legal System}

The law that prevailed in the Malay states (Malaya) before the British intervention was the Perpatih custom which was mostly in the territory of Negeri Sembilan and some parts of Malacca, as well as the Temenggong custom in other parts of the peninsula, with its local diversity. Most of the laws were unwritten and even Perak, which had three law books, had to admit that as late as 1878 , most of the laws in Perak were still unwritten, although generally understood.

The British faced many problems during their intervention. The most pressing issues such as slavery, forced labor, and land ownership were solved by the Slavery Ordinance, Forced Labor Ordinance, and Defense Regulations. The Defense Regulations require landowners to register their title to the Office of Defense and establish procedures for the inheritance of land to their descendants, without specifying what the inheritance law is. Feeling this solution was in line with Malayan customary 
law, the defense officials applied customary law in this case. Kadhis who are often asked for opinions on inheritance rights have stated this customary law as Islamic law many times. However, from these cases and the decisions of the State Councils of Perak, Pahang and Selangor, it is clear that until 1970, property and inheritance laws in the Malaysian states were Malay customary law. (Riyanto, 2017)

The differences of opinion that arise between local officials and the judge's decision appear to require a comprehensive study of the structure and principles of Malay customary law regarding wealth and inheritance. This seems to apply to Negeri Sembilan and Malacca where until now the matrilineal structure is still the basis of customary law. This also applies to other states where customary law still plays an important role in law enforcement. To assist the government in all matters concerning Islamic religion and customs, Malay Religious and Customary Councils have been established in all states.

UU no. 6/1951 defines Malay adat as part of the adat which has legal force that has been enforced or enforced in the state of Perak and which is generally known as "matrimonial property" including other adat practices which include "resam custom". Matrimonial properties are customs regarding joint wealth of husband and wife, and resam customs are ethics or traditions. The problem at that time was to establish this customary law without being influenced by Islamic views. The cases cited by the Supreme Court Justice E.N Taylor in his book Malay Family Law, show differences of opinion on this issue among Khadis, who often declare Malay adat rules as Islamic law. (Riyanto, 2017)

In the various agreements agreed upon by the Malay rulers of various countries and the British rulers, in which the Malay rulers agreed to accept the British opinion, it has been clearly established that this British opinion or view does not apply to matters relating to Malay religion and customs. Although this agreement has been reached, we are witnessing in all the states of Malaysia, directly or indirectly the UK has interfered with Islamic law and its implementation.

The expansion of British influence has indirectly supported the spread of British law. On the advice of British Residents, sultans of Malaysia have enacted a number of laws that adhere to the principles of British law adopted by India. Penal laws imitating 
the Indian were first passed in Perak by a Council decision of 28 June 1884. The Indian Contracts Act was first enacted in Selangor through the Selangor Court Decree 1893 and later through the laws of Perak, Selangor and Negeri Sembilan 1899 and Pahang 1990. The Indian Criminal Procedure Code was also passed and enforced in various states in 1897 and later 1903, and this legislation introduced the Torrens land registration system. The impact of this legislation replaces Malay Islamic law with legislation based on British legal principles.

The British Residents also encouraged Malay businessmen to establish high courts in each state. Prior to 1896, the appeal process in every Malay state was submitted to the Resident Court with a final appeal to the Sultan in the Council. In 1896, the Decrees and Regulations of the Commissioner of Law came into effect and this regulation abolished the Courts of Resident and Sultan in the Council and made the Commissioner of Law the last Court of Appeal for the federation. He was appointed by sultans with the consent of the resident, and he had been a judge for at least ten years. He accepts appeals from senior judges who hold unlimited jurisdiction. This system of Senior Judges was introduced at different times in the four states and these judges are other civil servants. In 1905, the Courts Law was enacted and abolished the Commissioner of Law and Senior Judge. The Supreme Court is formed and consists of a Chairman (Chief Legal Commissioner) and two legal commissioners who are appointed by the Resident General with the approval of the High Commissioner. Finally, Supreme Court was added with a third Legal Commissioner. The Court of Appeals consists of two or three judges. Through the Government of Appeals of the State of the Federation of Malaya in the Council of 1906, which was passed by the King, a provision was made for the process of appeals in civil actions from the new Supreme Court to the Royal Council. In 1821, through legislation in the three countries, the Commissioner of Law was made ex-officio for the Straits of Malacca and Johore and the judges in these two areas became ex-officio law commissioners. In 1923 it was established that the Court of Appeals for the Federated States of Malaya should consist of not less than three judges. In 1925, the positions were changed from Chief Law Commissioner and Legal Commissioner to Chief Justice and Judge. 
The practice established by the judges was strengthened when in 1937 the Civil Code law was enacted in the federated states of Malaya and established the acceptance of English law. In 1951, this law was extended to other states, and 1956 the Civil Code law introduced British law to the entire Federation of Malaya.

Provisions have been made in all states for the registration of Islamic marriages and divorces, but there is no statutory regulation regarding the inheritance of moslem wealth. Courts in the states of Malaya used to apply Islamic law in all these cases, not only on the wealth of those who died without a will, but also those who died in a will.

In Sabah and Sarawak, a number of local customs have been legalized. In a number of bulletins, Wooley describes certain features of customary law in the hamlets, murut and kwijan in Sabah. In Sarawak, several customary laws have been promulgated and incorporated into the Original Customary Law Code, which came into effect in 1955. The original Customary Law Code approved by Rajah (King) Brooke crystallized in the form of rigid unwritten law.

The "Unwritten Law" in these Borneo states consists essentially of indigenous tribal laws and customs in several areas, including Islamic Law and other indigenous laws and systems; The Chief Justice of Sarawak stated that all of these laws cover Dayak Islamic customs as well as other customs regarding marriage and inheritance as well as certain customs that impose criminal sanctions, for example for adultery and other illicit relationships understood in Malay and Dayak customs. Sarawak gives official recognition to escrow in Islam. In both Sarawak and Sabang, there are laws governing moslem worship and the implementation of Islamic law.

The customs adopted by certain other tribes are also carried out. For example, in relation to inheritance law, the customary law of Chinese inheritance has long been recognized by the Sarawak courts and the Sarawak courts are willing to enforce this law even though the Chinese are not natives of Sarawak. It should be noted, however, that in Sarawak, Chinese customary law is enforced as long as it is recognized by legislation, but no more. 
For example, the High Court has the power to grant divorce to those who marry according to Chinese custom, but that custom does not recognize divorce without a decision or order of the High Court.

When James Brook became King of Sarawak, one of the first things he did was prepare eight laws. These eight laws were written in Malay and published in 1843. All laws stipulate punishments for murder, robbery and "other heinous activities"' allowing everyone to trade or work according to their will and enjoy profits and protect Dayak people from exploitation, but do not provide freedom of traffic and commerce.

The regions in Kalimantan adhere to the British case system, the British equivalence doctrine and the generally applicable British statutes. Enforcement of all British legal products is only possible by local custom. This enforcement is based on the 1949 Sarawak Law Ordinance and the 1951 Sabah Law Ordinance.

The written law that is unique to Sabah and Sarawak is basically derived from the legislation in force in the Malay countries and Singapore, which then borrowed many written regulations from India and England. The clearest examples can be seen written from India and England. The clearest examples can be seen in the Criminal Code and the Criminal Procedure Code, basically the Malay and Indian Codes.

After the liberation of Malaya in 1946, England military rulers established a military government in Malaya. This government exercises full legislative, judicial, executive and administrative powers.

The initial decision has revived all the laws that had been in effect during the Japanese invasion. However, this decision must meet the various provisions of each decision, and as long as the military permits and the Civil Affairs Officer considers the decision to be enforceable. This initial decision has given the Civil Affairs Officer a very wide range of wiggle room, and with 77 decisions in Malaysian Federation and 61 in Singapore, the public is unsure of the law.

By providing an opportunity to restore civil law, the British Military Administration imposed a moratorium on certain financial claims. Civil administration was suspended but enforcement of the law was soon carried out and courts were set up throughout the region. The law that is used is generally the law that was in effect during 
the Japanese invasion, which is equipped with various regulations from the military government. The procedure is simplified without violating the principles of fairness.

The court set up to try war criminals must also decide whether the accused is guilty of declaring war on the Kingdom. The British Military Government ended on 31 March 1946, and the civilian government returned to power on $1^{\text {st }}$ April.

Since Independence, there has been a tendency in Malaysia and Singapore to adopt models other than the British model of legislation. The Company Law 1965, Insurance Law 1963 and Wage Law 1967 in Malaysia were based on Australian models and these models were followed by Singapore. In Singapore, the Land Tenure Law and the Industry Law are also based on the Australian model. The Women's Charter in Singapore, although based on the British model, borrows heavily from Australian, New Zealand and even Chinese legislation.

Currently, the courts in Malaysia and Singapore have a local composition. For a long time, appeals against Malaysian court decisions brought to the Royal Law Committee in the UK have been allowed. In 1978, appeals relating to criminal and administrative matters against the Royal Committee were abolished and in 1984 appeals to the Committee were abolished altogether.

Since the separation of Singapore from Malaysia, the legal systems in Malaysia and Singapore have been separated and the courts appear to be different. One important link remains in the form of the Malaysian Legal Journal which publishes court reports from both countries. (ASEAN Law Association, 1995, p. 84-90)

\section{CONCLUSION}

The elements in the legal system, in general both Indonesia and Malaysia have similarities, in terms of 1 ) The structure (frame or framework) of the highest judicial institutions such as the Supreme Court and the judicial institutions below it as well as the implementing institutions of laws and regulations, 2) The regulations, rules, and patterns of real behavior in various fields of life of the citizens concerned, 3) Attitudes towards the law and legal system of citizens in the form of beliefs, values, awareness, ideas, and expectations that make the legal process run. 
Specifically, there are differences between Indonesia and Malaysia. This is caused by 1) a structure that is based on local legal traditions and domestic legal traditions influenced by major legal traditions in the world (contemporary European legal traditions, anglo-saksis legal traditions, and legal traditions according to Islamic teachings), 2) Real rules, rules, and patterns of behavior in various fields in the lives of the citizens concerned, which are influenced by the Constitution and the laws and regulations under it, whose creation is influenced by local/domestic and global legal traditions, 3) Attitudes towards the law and legal system of citizens in the form of beliefs, values, awareness, ideas and hopes make the legal process run that is adaptive to the situation, conditions and problems faced by the country concerned.

\section{REFERENCES}

ASEAN Law Association, (1995). ASEAN legal systems, Butterworths Asia, Singapore, Malaysia, Hongkong.

Friedman, L. M. (1998). American Law An Introduction (Revised an). New York, London: W. W.Norton \& Company.

Manan, B. (1995). Pertumbuhan dan Perkembangan Konstitusi Suatu Negara. Bandung: CV. Mandar Maju.

Nusantara, A. H. G. (1986). Kebijaksanaan dan Strategi Pembangunan Hukum di Indonesia: Sebuah Tinjauan Kritis Politik Pembinaan Hukum Nasional, dalam Artidjo Alkostar dan M. Sholeh Amin, Pembangunan Hukum Dalam Perspektif Politik Hukum Nasional. Jakarta: CV. Rajawali.

Peaslee, A. J. (1985). Constitutions of Nations: Volume II-Asia, Australia and Oceania (Revised 4t). Dordrecht, Boston, Lancaster: Martimus Nijhoff Publisher.

Rahardjo, S. (1986). Ilmu Hukum (Cetakan Kedua). Bandung: PT. Alumni.

Riyanto, A. (2017). Sistem Hukum Negara-Negara Asia Tenggara. Jurnal Hukum \& Pembangunan, 37(2), 265. https://doi.org/10.21143/jhp.vol37.no2.1479

Manan, B. (1999). Reorientasi Politik Hukum Nasional. Yogyakarta: Diskusi IKAPTISI UGM. . (2000). Peranan Hukum Menuju dan Dalam Indonesia Baru, Surabaya: MUNAS KAHMIL. 